Bain, W.M., et al., 2021, Evidence for iron-rich sulfate melt during magnetite(-apatite) mineralization at El Laco, Chile: Geology, v. 49, https://doi.org/10.1130/G48861.1

SUPPLEMENTARY MATERIALS FOR:

\title{
Evidence for iron-rich sulfate melt during magnetite-(apatite) mineralization at El Laco, Chile
}

Wyatt M. Bain ${ }^{1}$, Matthew Steele-MacInnis ${ }^{1 *}$, Fernando Tornos $^{2,3}$, John M. Hanchar ${ }^{3}$ Emily Creaser ${ }^{1}$, Dorota K. Pietruszka ${ }^{3}$

${ }^{1}$ Dept. of Earth \& Atmospheric Sciences, University of Alberta, Edmonton, AB T6G 2E3, Canada

${ }^{2}$ Instituto de Geociencias (IGEO, CSIC-UCM), Dr Severo Ochoa, 7, 28040 Madrid, Spain

${ }^{3}$ Department of Earth Sciences, Memorial University of Newfoundland, St. John's, NL A1B 3X5, Canada

*Correspondence to: steelema@ualberta.ca

\section{SUPPLEMENTAL GEOLOGIC BACKGROUND AND SAMPLE DESCRIPTION}

El Laco is a $35 \mathrm{~km}^{2}$, Pliocene (5.3-1.6 Ma, Naranjo et el., 2010) volcanic complex situated in the Central Volcanic Zone (CVZ) in the northern Chilean Andes. The complex consists of porphyritic to massive, flow banded andesite and pyroclastic deposits which emanate from a central volcanic edifice and have igneous textures indicative of subaerial eruptive processes (Sillitoe and Burrows, 2002). The andesites in the complex are compositionally close to trachyandesite and chemically indistinguishable from the nearby Llullaillaco and Lascar volcanos (Matthews et al., 1994; 1999) and other volcanoes in the Central Volcanic Zone (Harmon et al., 1984). The volcanic center is situated in an area that underwent extensive crustal thickening during the Miocene (Zandt et al., 1994; Allmendinger et al., 1997; Trumbull et al., 1999) and is underlain by alluvial conglomerates and siltstones of the Oligocene San Vicente formation; sandstones, mudstones, limestones, and evaporites of late Cretaceous-Tertiary Salta group; and Ordovician-Silurian age sedimentary basement rocks (Matthews et al 1996; Tornos et al., 2017). The crustal thickening and successive sequences of sedimentary rock underlaying the 
complex likely account for significant crustal contamination observed in the andesites in this system (Matthews et al., 1994; Zandt et al., 1994; Trumbull et al., 1999; Velasco et al., 2016). Magnetite mineralization in the El Laco system is dominantly low in $\mathrm{Ti}(<0.15 \%)$ and high in V (90-2600 ppm), and occurs in sub-horizontal stratabound orebodies and discordant subvertical feeder dikes that cross-cut the host andesite (Naranjo et al., 2010; Broughm et al., 2017). The stratabound orebodies are interbedded with the andesite flows and form semicircular, lobate structures that project outward from the central volcanic edifice, fed by dikes that extend under the complex (Velasco et al., 2016). The stratabound ores have abundant volcanic textures including flow structures, vesicles, columnar jointing, scoriaceous surfaces with pahoehoe banding, and pyroclastic deposits (Nyström and Henríquez, 1994; Naslund et al., 2002; LLedó, 2005; Nyström et al, 2016; Tornos et al., 2016). Along their bases, the stratabound ores overlie brecciated andesite flows cemented by magnetite (Sillitoe and Burrows, 2002). The feeder dikes also contain abundant magmatic textures such as columnar jointing, sharp contacts with host rocks, and vesiculated centerlines. In addition, many areas in the system are capped by layered sequences of friable hematite-rich ore that hosts rounded magnetite fragments interpreted as volcanic bombs (Nyström and Henríquez, 1994).

Hydrothermal alteration forms a pervasive overprint throughout $\sim 30-40 \%$ of the complex (Tornos et al., 2017) and consists of late acid alteration that overprints earlier alkali-calcic and propylitic assemblages. The alkali-calcic alteration consists of albite-dominated, Na-Ca alteration that transitions into a slightly later K-Ca alteration assemblage, both of which are surrounded by propylitic alteration. In many cases (e.g. at Pasos Blancos and Laco Norte), the alkali-calcic alteration is focused on areas of pervasive brecciation, wherein fragments of host andesite are surrounded or replaced by course-grained diopside, anhydrite, Ti-poor magnetite, and scapolite.

Massive stratabound ore bodies, feeder dikes and zones of alkali-calcic alteration are commonly capped by diopside-magnetite-anhydrite veins which are in turn overprinted by late acid alteration. These veins, first described by Naranjo et al., (2010), are most abundant in the Pasos Blancos breccia pipe and are the main subject of the present study.

Diopside-magnetite-anhydrite veins were collected from drill core, from depths of $\sim 314$ to $397 \mathrm{~m}$ below the present land surface at the Pasos Blancos breccia pipe in the central region of the El Laco volcanic complex (Table S1, 67²9.411'W; $\left.23^{\circ} 50.554 ' \mathrm{~S}\right)$. The Pasos Blancos 
breccia pipe occurs a cylindrical zone of magnetite-diopside-rich breccia and ellipsoidal magnetite masses. The densest concentrations of magnetite coincide with the densest concentrations of diopside-magnetite-anhydrite veins and the breccia body as a whole is overprinted by pervasive acid-sulfate alteration and capped by a massive gypsum mound. Veins sampled from this area occur along the upper boundary of a massive magnetite orebody and appear to be entirely intrusive, lacking a connection to or association with the magnetite feeder zones that grade into the extrusive, stratabound orebodies near the surface. These veins are texturally similar to pegmatites, in that they have a strong zonation in mineralogy and contain well developed unidirectional textures defined by coarse, euhedral (in some cases, graphic textured) diopside and magnetite which appear to have grown inward perpendicular to the vein margin (Fig. 1C-D; S1). Along the central axis, diopside and magnetite are commonly intergrown with anhedral anhydrite and minor pyrite. Relative to the host andesite, anhydrite and diopside from these veins show a distinctly crustal signature with ${ }^{87} \mathrm{Sr} /{ }^{86} \mathrm{Sr}$ of 0.7080 to 0.7083 , present day $\varepsilon \mathrm{Nd}$ of -5.1 to -4.6 , and $\delta^{18} \mathrm{O}$ of 8.1 to 9.8 for anhydrite and 7.1-8.6 for diopside (Tornos et al., 2017).

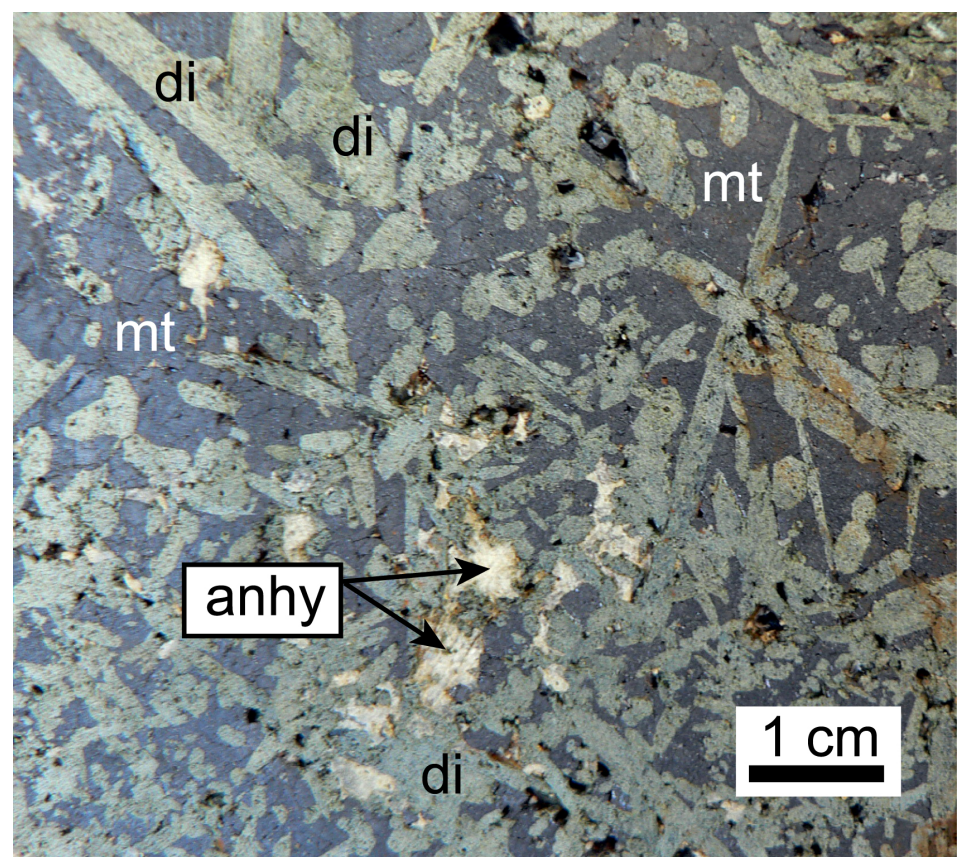

Figure S1: Cut surface of a diopside-magnetite-anhydrite vein in drill core from Pasos Blancos, showing the coarse-grained ("pegmatitic") texture of the vein, and the paragenetic relationships between relatively early diopside and coeval magnetite transitioning to late interstitial anhydrite. 
Diopside-magnetite-anhydrite veins show sharp contacts with altered host andesite (Fig. 1C) and commonly crosscut breccia zones characterized by pervasive alkali-calcic alteration.

The alkali-calcic alteration associated with these veins is characterized by pervasive albitization, potassic alteration and replacement of primary augite and enstatite-pigeonite by diopside and magnetite. Alkali-calcic alteration is, in turn, overprinted by pervasive $\mathrm{K}-\mathrm{Ca}$ alteration characterized by mineral assemblages containing sanidine, diopside, magnetite, scapolite, fluorapatite, and minor magnetite (Tornos et al., 2017).

Pegmatite-hosted magnetite from this study is identical to the "magnetite- $\alpha$ " described by Ovalle et al., (2018). This magnetite is characterized by aggregates of titanomagnetite with welldeveloped ilmenite exsolution lamellae ("trellis texture") which are visible in EDS maps (Fig. S2). Magnetite with this habit at El Laco has the highest trace element contents compared to other magnetite varieties described by Ovalle et al. (2018).

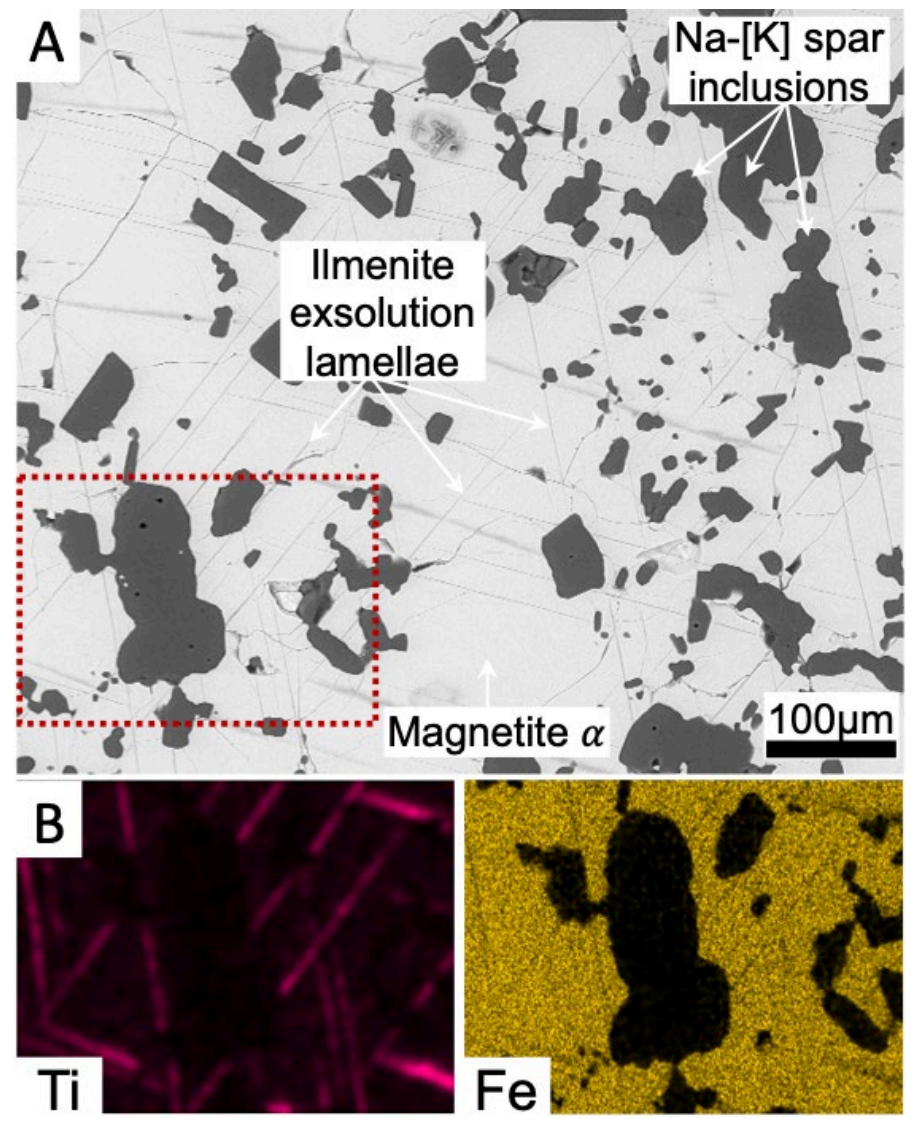

Figure S2: A: Back-scattered electron image of magnetite from diopside-magnetite-anhydrite veins. This magnetite was sampled form a depth of $\sim 325 \mathrm{~m}$ below the surface and shows well developed ilmenite exsolution lamellae ("trellis texture") consistent with the magnetite- $\alpha$ reported by Ovalle et al., 2018. B: X-ray maps of the area outlined by a red dotted line in panel A. The ilmenite exsolution lamellae are apparent by their strong Ti signal. 


\section{SUPPLEMENTAL METHODS}

\section{Sample preparation}

Each sample was prepared into doubly-polished thick sections with an approximant thickness of 100-150 $\mu \mathrm{m}$. Table $\mathrm{S} 1$ shows scanned images of the samples examined in this study, along with short descriptions of each.

\begin{tabular}{|c|c|c|}
\hline$p$ & $\begin{array}{c}\text { LCO-252 } \\
\text { (Drillhole } \\
\text { EPI-0811, } \\
397 \mathrm{~m} \text { ) }\end{array}$ & $\begin{array}{l}\text { Intergrown coarse grained, euhedral- } \\
\text { subhedral magnetite (opaque) and diopside } \\
\text { (green) }\end{array}$ \\
\hline & $\begin{array}{c}\text { LCO-253 } \\
\text { (Drillhole } \\
\text { EPI-0811, } \\
345.3 \mathrm{~m} \text { ) }\end{array}$ & $\begin{array}{l}\text { Intergrown coarse grained, euhedral- } \\
\text { subhedral magnetite (opaque) and diopside } \\
\text { (green) }\end{array}$ \\
\hline & \begin{tabular}{|c} 
LCO-204 \\
(Drillhole \\
LCO- \\
0932, \\
324.9 )
\end{tabular} & $\begin{array}{l}\text { Coarse grained, euhedral-subhedral diopside } \\
\text { with minor intergrown anhedral-subhedral } \\
\text { magnetite grains (opaque). Minor quartz and } \\
\text { anhydrite interstitial between diopside. }\end{array}$ \\
\hline 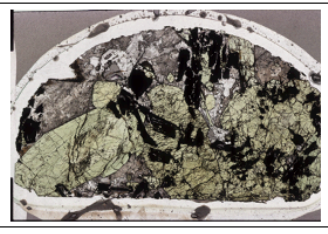 & \begin{tabular}{|c} 
LCO-207 \\
(Drillhole \\
LCO- \\
0932, \\
314.25 ) \\
\end{tabular} & $\begin{array}{l}\text { Coarse grained, euhedral-subhedral diopside } \\
\text { with intergrown anhedral-subhedral blebs of } \\
\text { magnetite (opaque). Minor quartz and } \\
\text { anhydrite interstitial between diopside. }\end{array}$ \\
\hline
\end{tabular}

Table S1: Diopside-magnetite-anhydrite pegmatite samples which were the primary focus of this study.

\section{Inclusion petrography and microthermometry}

Inclusion petrography followed the methods described by Goldstein and Reynolds (1994) and focused on identifying and characterizing temporally distinct primary and secondary fluid inclusion assemblages (FIAs). The polycrystalline inclusions characterized in this study were apparent from their granular appearance and birefringence that contrasted with that of the host (Fig. 2A). In the case of magnetite hosted inclusions, we characterized breached inclusions that were exposed at the surface by polishing. Confident identification of breached inclusions was done using textural observations of the distribution of inclusions and was guided by previous petrographic and compositional analysis of inclusions in translucent phases. Petrography and 
analyses mostly focused on inclusions hosted in diopside and albite as these were the most abundant translucent phases which hosted clearly defined FIAs which could by analyzed by microthermometry. Observations and analyses were also made of inclusions hosted in magnetite and apatite as these phases also hosted inclusions with similar phase assemblages as those observed in diopside and albite.

No aqueous liquid-rich inclusions were observed in any of the samples analyzed in this study, and polycrystalline inclusions lacked a clear aqueous phase at room temperature. As a result, low temperature $\left(<0^{\circ} \mathrm{C}\right)$ microthermometry was not undertaken. All microthermometric observations were made between $20-1150^{\circ} \mathrm{C}$ using a Linkam TS1400XY stage calibrated using the critical point of $\mathrm{H}_{2} \mathrm{O}\left(374^{\circ} \mathrm{C}\right)$, the 1 -atm $\alpha / \beta$ transition of quartz $\left(574^{\circ} \mathrm{C}\right)$, and the triple point of $\mathrm{NaCl}\left(801^{\circ} \mathrm{C}\right)$. Estimated precision and accuracy of the measurements at temperatures $>500{ }^{\circ} \mathrm{C}$ is $\pm 1{ }^{\circ} \mathrm{C}$. Heating was conducted on individual chips cut from the samples shown in Table S1. Sample chips were heated only once in a continuous ramp at a rate of $10-30{ }^{\circ} \mathrm{C}$ per minute. Lower rates were used in proximity to the temperature of observed phases changes. Temperatures did not exceed $1150^{\circ} \mathrm{C}$ in any of our experiments.

\section{Raman Spectroscopy}

Raman spectroscopy was used to identify individual phases in polycrystalline inclusions. At least 15 individual analyses were done on each inclusion to ascertain the phases present and constrain their spatial distribution and abundance. The Raman system consisted of a Thermo DXR2 dispersive Raman microscope and a 532-nm green laser with power range $0.1-10$ coupled to a conventional microscope with 10x, 50x and 100x objectives. All reported Raman spectra in this study were collected using the $100 \mathrm{x}$ objective and a spot size of $0.7 \mu \mathrm{m}$. All spectra were acquired on unoriented grains using a laser power of $20 \mathrm{~mW}$ and two to three, 10 30 s exposures summed to the final reported spectra. Baseline subtraction was done using the Fityk $^{\mathrm{TM}}$ software package. Spectra were interpreted using the RRUFF database (Lafuente et al., 2016). Luminescence of the host mineral was mostly weak or absent, but when observed, was corrected using the Omnic spectral analysis software.

\section{Scanning Electron Microscope - Energy Dispersive Spectroscopy (SEM-EDS)}


Back-scattered electron (BSE) images, and energy dispersive spectroscopy (EDS) were used to analyze the composition of crystalline phases and solid residues in polycrystalline inclusions exposed at the samples surface via sample polishing. The analyses were done at the Earth and Atmospheric Sciences Department at the University of Alberta. The system consisted of a Zeiss EVO SEM with a $\mathrm{LaB}_{6}$ electron source and Bruker energy dispersive X-ray spectroscopy (EDS) system with a silicon drift detector. The resolution was $123 \mathrm{eV}$ and the window area was $10 \mathrm{~mm}^{2}$. Analyses were done in variable pressure mode with a $100-\mu \mathrm{m}$ aperture, an acceleration voltage of $20-25 \mathrm{kV}$, a beam current of 225-275 pA, and a 7-8.5 mm working distance. EDS element maps were collected using collection times of 10-30 min. None of the samples were carbon coated at any point.

\section{SUPPLEMENTAL RESULTS}

\section{Inclusion Petrography}

Polycrystalline inclusions are a ubiquitous feature throughout the studied samples and occur in all studied minerals including diopside, magnetite, albite, and apatite. Polycrystalline inclusions have a round or elongate negative crystal shapes and range in size from 5-30 $\mu \mathrm{m}$. Polycrystalline inclusions appear completely filled with crystalline material which is mostly translucent, but also includes 1-2 round or square opaque crystals. All of these inclusions also contain a vapor phase which either fills the interstitial space between crystalline phases or is concentrated along the outer wall of the inclusion. Polycrystalline inclusions occur in both primary (along growth zones; Fig. 2A) and secondary assemblages (along healed fracture planes that cross-cut primary assemblages) in all host phases. In diopside, albite, and apatite these inclusions are readily distinguished in cross-polarized light by the contrast between their birefringence and that of their host crystals (Fig S3). In secondary assemblages, polycrystalline inclusions occasionally occur alongside coeval vapor-rich inclusions, which have roughly the same sizes and shapes as the polycrystalline inclusions. Vapor-rich inclusions are distinctive in that they contain no crystalline or liquid phases at room temperature and hence appear black in transmitted light. 


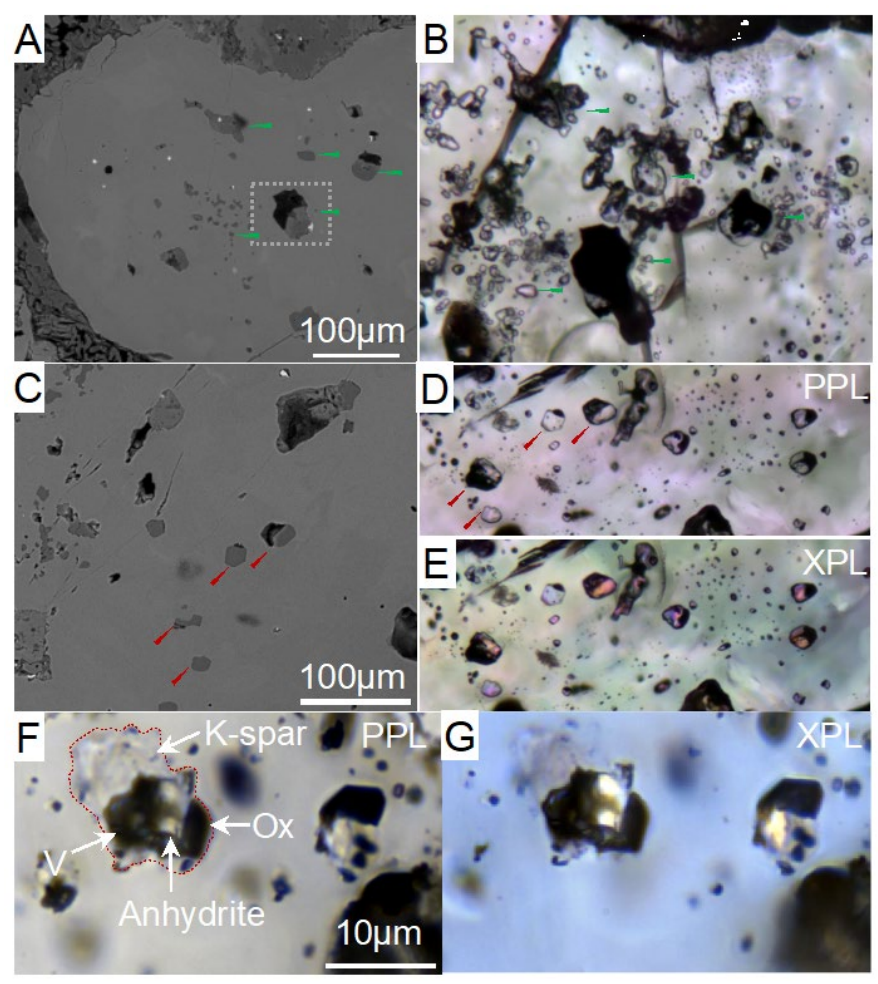

Figure S3: A. Back-scattered electron image of a diopside grain containing an assemblage of primary, silicate-rich polycrystalline inclusions. Green arrows denote polycrystalline inclusions that are also visible in panel B. The area shown in Fig 2E is outlined by a grey dotted line. B. Photomicrograph of silicate-rich polycrystalline inclusions. C. Back-scattered electron image of a diopside grain with primary, silicate-rich polycrystalline inclusions. Red arrows denote polycrystalline inclusions that are also visible in panel D. D. Photomicrograph of silicate-rich polycrystalline inclusions in plane polarized light (PPL). E. Area shown in panel D in crosspolarized light (XPL). F. Albite-hosted polycrystalline inclusions in PPL. G. Area shown in panel F. in XPL.

\section{Inclusion Compositions}

The crystalline phases present in polycrystalline inclusions exposed at the surface of polished samples were analyzed with scanning electron microscope - energy dispersive spectroscopy (SEM-EDS). Inclusions in the cores of diopside grains are composed primarily of silicates (albite, K feldspar, and quartz; 40-45 vol\%), sulfates (anhydrite, glauberite; 40-45 vol\%), Ferich phases (hematite, pyrite, and ilmenite; 5-10 vol\%), and variable phosphate (Fig S4). The remaining volume of the inclusions consists of vapor. The sulfate and silicate portions of the inclusions are in roughly equal proportions and have a characteristic distribution in which the silicate phases are either concentrated along one edge of the inclusion (Fig 2E) or are surrounding a central mass of sulfate plus phosphate (Fig S4). This latter case was most 
commonly observed in albite-hosted inclusions, wherein the only silicate phases observed were $\mathrm{K}$ feldspar and quartz (owing to inward growth of albite along the inclusion-host interface). In both cases, the areas containing sulfate and phosphate appear partially excavated in back-scatter electron images as a result of the relative softness of sulfates and phosphates compared to the adjacent silicates.

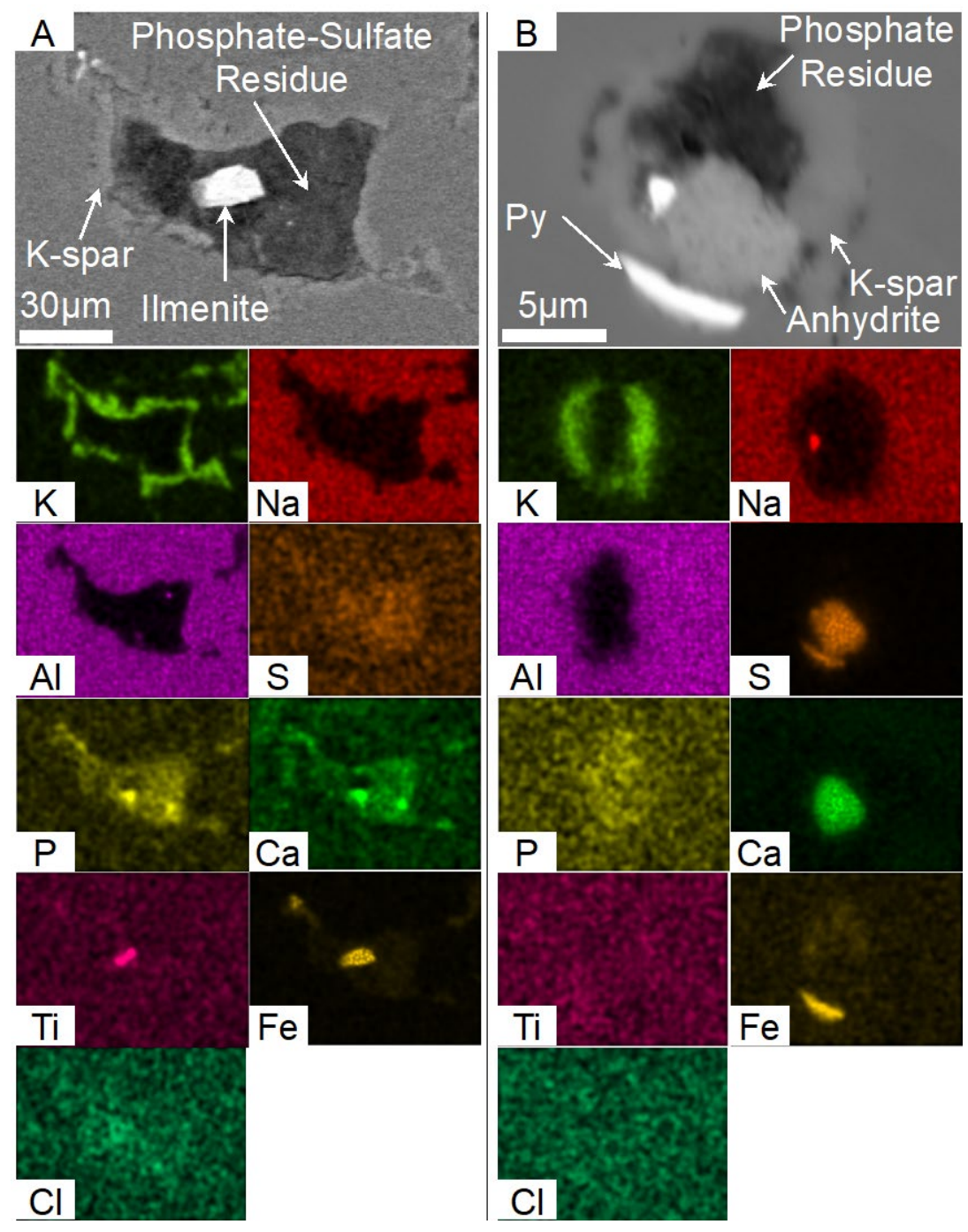

Figure S4. A. Back-scattered electron image of an albite-hosted polycrystalline inclusion with corresponding EDS maps. B. Back-scattered electron image of an albite-hosted polycrystalline inclusion similar to that shown in panel A with corresponding EDS maps. Note that the Fe-rich phase in this inclusion is pyrite (Py).

Paragenetically younger polycrystalline inclusions in the rims of host crystals and in secondary assemblages consist of $\sim 75-80$ vol\% sulfate with $\sim 5-10$ vol $\%$ hematite and 10-20 
vol\% vapor. Raman analysis of these inclusions in apatite also revealed presence of lesser allanite and natrite (Fig S5).

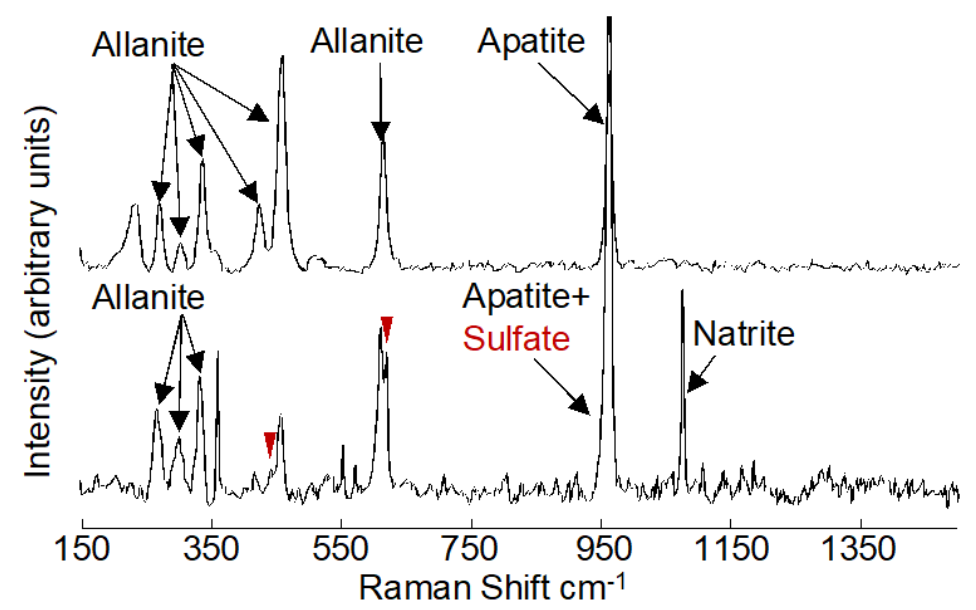

Figure S5. Raman spectra from an apatite-hosted, sulfate-rich inclusion showing allanite and natrite.

\section{Microthermometry}

Results of microthermometric analysis are shown in Table S2 along with additional photomicrographs of inclusions during high-temperature experiments in Fig S6. 


\begin{tabular}{|c|c|c|c|c|c|c|}
\hline $\mathrm{n}$ & $\mathrm{FIA}$ & Type & Host & $\mathrm{T}_{\mathrm{M}} 1^{\mathrm{st}}$ & $\mathrm{T}_{\mathrm{M}} \mathrm{F}$ & $\underline{\mathrm{T}_{\mathrm{H}} \mathrm{L}-\mathrm{V}}$ \\
\hline 1 & P FIA1 & $\mathrm{Pl}_{\mathrm{An}}$ & $\mathrm{Di}$ & $\sim 410$ & 711 & - \\
\hline 2 & P FIA1 & $\mathrm{Pl}_{\mathrm{An}}$ & $\mathrm{Di}$ & - & 720 & - \\
\hline 3 & P FIA1 & $\mathrm{Pl}_{\mathrm{An}}$ & $\mathrm{Di}$ & - & 730 & - \\
\hline 4 & P FIA1 & $\mathrm{Pl}_{\mathrm{An}}$ & Di & - & 724 & - \\
\hline 5 & P FIA2 & $\mathrm{Pl}_{\mathrm{An}}$ & $\mathrm{Di}$ & $\sim 346$ & 700 & 805 \\
\hline 6 & P FIA2 & $\mathrm{Pl}_{\mathrm{An}}$ & $\mathrm{Di}$ & $\sim 425$ & 714 & 803 \\
\hline 7 & P FIA2 & $\mathrm{PI}_{\mathrm{An}}$ & $\mathrm{Di}$ & - & 745 & - \\
\hline 8 & P FIA3 & $\mathrm{Pl}_{\mathrm{An}}$ & $\mathrm{Di}$ & - & 727 & 890 \\
\hline 9 & P FIA3 & $\mathrm{Pl}_{\mathrm{An}}$ & $\mathrm{Di}$ & - & 719 & 951 \\
\hline 10 & P FIA3 & $\mathrm{Pl}_{\mathrm{An}}$ & $\mathrm{Di}$ & - & 694 & 694 \\
\hline 11 & P FIA3 & $\mathrm{Pl}_{\mathrm{An}}$ & $\mathrm{Di}$ & - & 718 & - \\
\hline 12 & P FIA3 & $\mathrm{PI}_{\mathrm{An}}$ & $\mathrm{Di}$ & - & 720 & - \\
\hline 13 & P FIA4 & $\mathrm{Pl}_{\mathrm{F}}$ & $A b$ & $\sim 456$ & 764 & 910 \\
\hline 14 & P FIA4 & $\mathrm{Pl}_{\mathrm{F}}$ & $A b$ & $\sim 424$ & 766 & 846 \\
\hline 15 & P FIA4 & $\mathrm{Pl}_{\mathrm{F}}$ & $\mathrm{Ab}$ & $\sim 430$ & 719 & 789 \\
\hline 16 & P FIA5 & $\mathrm{Pl}_{\mathrm{F}}$ & $A b$ & $\sim 470$ & 734 & $>900$ \\
\hline 17 & P FIA5 & $\mathrm{Pl}_{\mathrm{F}}$ & $A b$ & - & 760 & - \\
\hline 18 & P FIA5 & $\mathrm{Pl}_{\mathrm{F}}$ & $A b$ & - & 760 & - \\
\hline 19 & P FIA5 & $\mathrm{Pl}_{\mathrm{F}}$ & $\mathrm{Ab}$ & - & 769 & - \\
\hline 20 & S FIA1 & $\mathrm{Pl}_{\mathrm{An}}$ & $\mathrm{Di}$ & - & 764 & - \\
\hline 21 & S FIA1 & $\mathrm{Pl}_{\mathrm{An}}$ & $\mathrm{Di}$ & - & 784 & 940 \\
\hline 22 & S FIA1 & $\mathrm{Pl}_{\mathrm{An}}$ & $\mathrm{Di}$ & - & 782 & - \\
\hline 23 & S FIA1 & $\mathrm{Pl}_{\mathrm{An}}$ & $\mathrm{Di}$ & - & 782 & - \\
\hline 24 & S FIA1 & $\mathrm{Pl}_{\mathrm{An}}$ & $\mathrm{Di}$ & - & 782 & - \\
\hline 25 & S FIA1 & $\mathrm{Pl}_{\mathrm{An}}$ & $\mathrm{Di}$ & - & 782 & - \\
\hline 26 & S FIA1 & $\mathrm{PI}_{\mathrm{An}}$ & $\mathrm{Di}$ & - & 782 & - \\
\hline 27 & S FIA1 & $\mathrm{Pl}_{\mathrm{An}}$ & $\mathrm{Di}$ & - & 782 & - \\
\hline 28 & S FIA1 & $\mathrm{PI}_{\mathrm{An}}$ & $\mathrm{Di}$ & - & 782 & - \\
\hline 29 & S FIA2 & $\mathrm{Pl}_{\mathrm{An}}$ & $\mathrm{Di}$ & - & 720 & - \\
\hline 30 & S FIA2 & $\mathrm{PI}_{\mathrm{An}}$ & $\mathrm{Di}$ & $\sim 400$ & 700 & 700 \\
\hline 31 & S FIA2 & $\mathrm{PI}_{\mathrm{An}}$ & $\mathrm{Di}$ & - & 705 & - \\
\hline
\end{tabular}

Table S2: Microthermometric data for primary (P) and secondary (S) FIAs referenced in this study. $\mathrm{T}_{\mathrm{M}} 1^{\text {st }}=$ First melting temperature; $\mathrm{T}_{\mathrm{M}} \mathrm{F}=$ final melting temperature; $\mathrm{T}_{\mathrm{H}} \mathrm{L}-\mathrm{V}=$ liquidvapor homogenization temperature. 


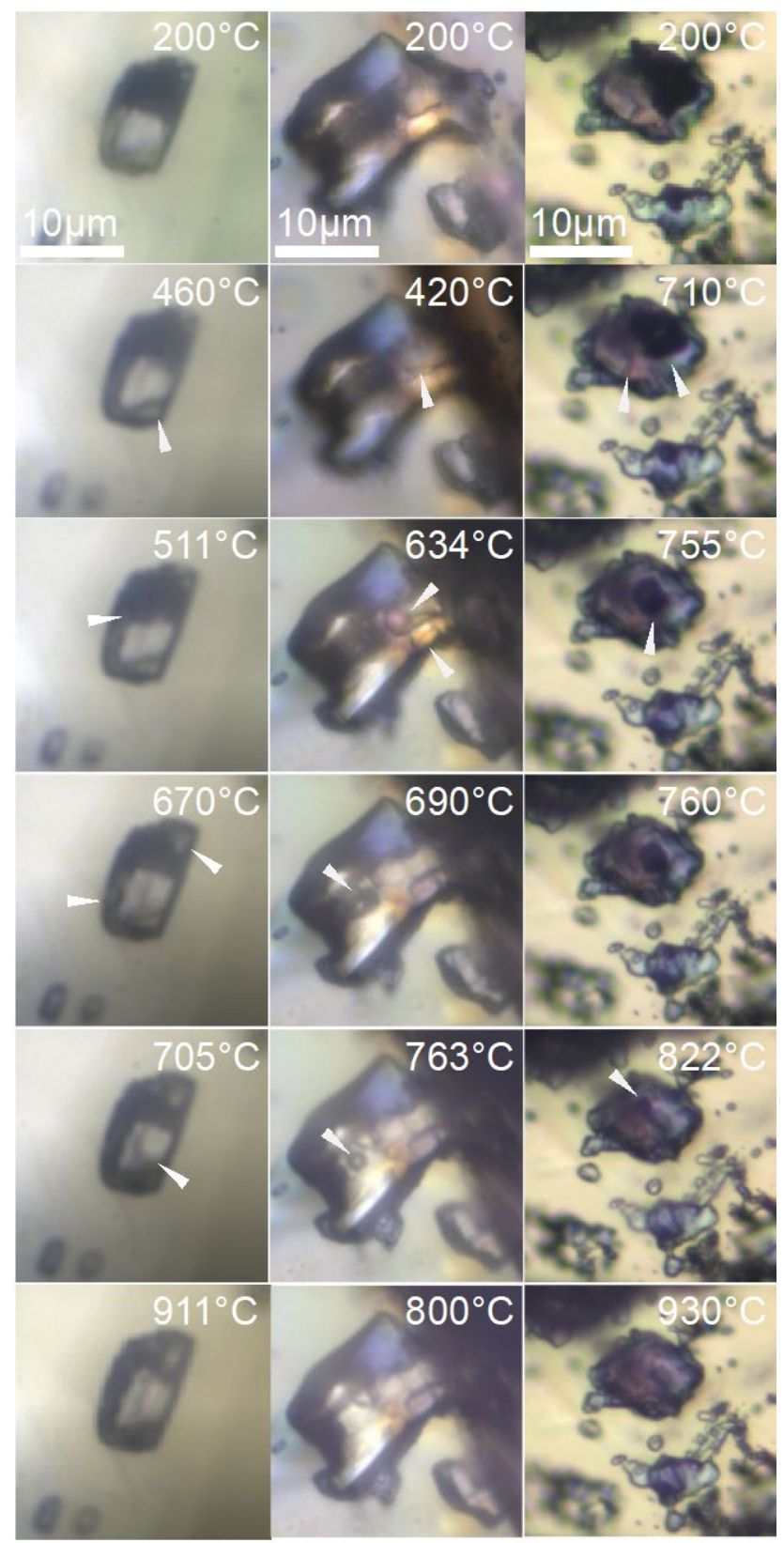

Figure S6. Temperature series of diopside-hosted polycrystalline inclusions.

\section{REFERENCES}

Allmendinger, R.W., Jordan, T.E., Kay, S.M., and Isacks, B.L., 1997, The evolution of the Altiplano-Puna plateau of the Central Andes: Annual Review of Earth and Planetary Sciences, v. 25, p. 139-174.

Broughm, S., Hanchar, J.M., Tornos, F., Attersley, S., and Westhues, A., 2017, Mineral chemistry of magnetite from magnetite-apatite ores and their host rocks in Sweden and 
Chile: Mineralium Deposita, v. 52, p.1223-1244, https://doi.org/10.1007/s00126-0170718-8.

Goldstein, R. H. \& Reynolds, T. J., 1992, Systematics of Fluid Inclusions in Diagenetic Minerals: SEPM Society for Sedimentary Geology, v. 31, https://doi.org/10.2110/scn.94.31 .

Harmon, R.S., Barreiro, B.A., Moorbath, S., Hoefs, J., Francis, P.W., Thorpe, R.S., Déruelle, B., McHugh J., and Viglino, J.A., 1984, Regional O-, Sr-, and Pb-isotope relationships in late Cenozoic calc-alkaline lavas of the Andean Cordillera: Journal of the Geological Society, 141, p. 803-822. https://doi.org/10.1144/gsjgs.141.5.0803 .

Lafuente, B., Downs, R. T., Yang, H. \& Stone, N., 2016, The power of databases: The RRUFF project. in Armbruster, T., and Danisi R.M., eds., Highlights in Mineralogical Crystallography: p. 1-29, https://doi.org/10.1515/9783110417104-003 .

Lledo, H.L., 2005, Experimental Studies on the origin of iron deposits; and mineralization of Sierra La Bandera, Chile [Ph.D. thesis]: Binghamton, State University of New York at Binghamton, 271p.

Matthews, S.J., Jones, A.P. and Beard, A.D., 1994: Buffering of melt oxygen fugacity by sulphur redox reactions in calc-alkaline magmas: Journal of the Geological Society, London v. 151, p. 815-823, https://doi.org/10.1144/gsjgs.151.5.0815 .

Matthews, S., Sparks, R., and Gardeweg, M., 1999. The Piedras Grandes-Soncor eruptions, Lascar ulcano, Chile: evolution of a zoned magma chamber in the Central Andean upper crust: Journal of Petrology. v. 40, p. 1891-1919, https://doi.org/10.1093/petrology/40.12.1891 .

Naranjo, J.A., Henríquez, F., and Nyström, J.O., 2010, Subvolcanic contact metasomatism at El Laco Volcanic Complex, Central Andes: Andean Geology, v. 37, p. 110-120, https://doi.org/10.4067/S0718-71062010000100005.

Naslund, H.R., Henriquez, F., Nystr.m, J.O., Vivallo, W., and Dobbs, F.M., 2002, Magmatic iron ores and associated mineralisation; Examples from the Chilean High Andes and Coastal Cordillera, in Porter, T.M., ed., Hydrothermal Iron Oxide Copper-Gold \& Related Deposits: A Global Perspective, Volume 2: Adelaide, Australia, PGC Publishing, p. $207-$ 226. 
Nyström, J.O., and Henriquez, F., 1994, Magmatic features of iron ores of the Kiruna type in Chile and Sweden: Ore textures and magnetite geochemistry: Economic Geology, v. 89, p. 820-839, https://doi.org/10.2113/gsecongeo.89.4.820 .

Nyström, J.O., Henríquez, F., Naranjo, J.A., and Naslund, H.R., 2016, Magnetite spherules in pyroclastic iron ore at El Laco, Chile: American Mineralogist, v. 101, p. 587-595, https://doi.org/10.2138/am-2016-5505 .

Ovalle, J.T. et al., 2018, Formation of massive iron deposits linked to explosive volcanic eruptions: Scientific Reports. v. 8. p. 1-11, https://doi.org/10.1038/s41598-018-33206-3 .

Sillitoe, R.H., and Burrows, D.R., 2002, New field evidence bearing on the origin of the El Laco magnetite deposit, northern Chile: Economic Geology, v. 97, p. 1101-1109, https://doi.org/10.2113/gsecongeo.97.5.1101 .

Tornos, F., Velasco, F., and Hanchar, J., 2016, Iron-rich melts, magmatic, magnetite, and superheated magmatic-hydrothermal systems: The El Laco deposit, Chile: Geology, v. 44, p. 427-430, https://doi.org/10.1130/G37705.1 .

Tornos, F., Velasco, F. and Hanchar, J. M., 2017, The magmatic to magmatic hydrothermal evolution of the El Laco deposit (Chile) and its implications for the genesis of magnetiteapatite deposits: Economic Geology, v. 112, p. 1595-1628, https://doi.org/10.5382/econgeo.2017.4523 .

Trumbull, R.B., Wittenbrink, R., Hahne, K., Emmermann, R., Busch, W., Gerstenberger, H., and Siebel, W., 1999, Evidence for late Miocene to Recent contamination of arc andesites by crustal melts in the Chilean Andes $\left(25-26^{\circ} \mathrm{S}\right)$ and its geodynamic implications: Journal of South American Earth Sciences, v. 12, p. 135-155, https://doi.org/10.1016/S08959811(99)00011-5 .

Velasco, F., Tornos, F. and Hanchar, J.M., 2016, Immiscible iron- and silica-rich melts and magnetite geochemistry at the El Laco volcano (northern Chile): Evidence for a magmatic origin for the magnetite deposits: Ore geology reviews. v. 79, p. 346-366, https://doi.org/10.1016/j.oregeorev.2016.06.007 .

Zandt, G., Velasco, A.A., and Beck, S.L., 1994, Composition and thickness of the southern Altiplano crust, Bolivia: Geology, v. 22, p. 1003-1006, https://doi.org/10.1130/00917613(1994)022<1003:CATOTS $>2.3 . C O ; 2$. 